\title{
Evolving MPA Management in New Zealand: Between Principle and Pragmatism
}

\author{
Karen N. Scott ${ }^{\star}$ \\ Professor, School of Law \\ University of Canterbury, New Zealand \\ Karen.Scott@canterbury.ac.nz \\ This manuscript has not been published elsewhere and has not been submitted for consideration by any \\ other journal.

\section{Key Words} \\ Marine protected areas (MPA); New Zealand; reform
}

\begin{abstract}
In January 2016 New Zealand released a consultation document proposing a new MPA act designed to significantly reform current and now dated MPA policy. This article explores those reform proposals in the context of the current regulatory regime, international obligations and the best practice of selected other states. Whilst the proposed act provides for a much firmer legislative base from which to develop an MPA network to conserve biodiversity and ecosystem function, it is nevertheless limited in geographic and functional scope. As such, it represents a missed opportunity and undermines New Zealand's claims to be an international leader in ocean management.
\end{abstract}

\section{Introduction}

The designation of marine protected areas is an essential tool in modern ocean management and a cornerstone "of virtually all national and international conservation strategies." There is no universally agreed definition of a marine protected area (MPA) but the IUCN definition of a protected area as "a clearly defined geographical space, recognised, dedicated and managed, through legal or other effective means, to achieve the long-term conservation of nature with associated ecosystem services and cultural values" is widely applied. ${ }^{2}$ Currently, about 3.5 percent of the global ocean environment is subject to protected area status ${ }^{3}$ with the overwhelming majority of protected areas located in maritime zones under the jurisdiction of states. ${ }^{4}$ The international community has committed to designating 10 percent of the global ocean environment as protected areas by 2020 as part of the 2010 Aichi Biodiversity Targets. ${ }^{5}$ Aichi Target 11 stipulates that 
By 2020, at least 17 percent of terrestrial and inland water areas, and 10 percent of coastal and marine areas, especially areas of particular importance for biodiversity and ecosystem services, are conserved through effectively and equitably managed, ecologically representative and well connected systems of protected areas and other effective area-based conservation measures, and integrated into the wider landscapes and seascapes.

This target notably broadens the notion of the protected area and expressly incorporates reference to other "effective area-based conservation measures" and the need to integrate MPAs into seascape conservation more generally. This reflects the transformation of the MPA over the last two decades from a measure that is aimed at protecting small highly vulnerable and/ or valuable sites to a tool that is designed to integrate the management of multiple activities and threats within a spatial area. ${ }^{6}$ The slow progress towards designating a representative network of MPAs in part reflects the ecological and jurisdictional complexities associated with protected areas in the marine environment in contrast to the terrestrial environment. The ocean environment is three dimensional, fluid with large scales of connectivity as demonstrated by the range of migratory species, rapid dispersal of eggs and larvae as well as pollution. ${ }^{7}$ A wide variety of users have rights within the marine environment, particularly in relation to navigation, but in contrast to the terrestrial environment rights are not tenured and most do not constitute 'property'. Moreover, international law distinguishes between coastal state rights relating to the water column and the seabed, and this adds to the complexity of managing sites, particularly where the MPA is located within and beyond 200 nautical miles of the coast. ${ }^{8}$ 
New Zealand was an early pioneer in the field of marine conservation with the first MPA being proposed in 1965 in the area adjacent to the Leigh Marine Laboratory north of Auckland. ' The Cape Rodney-Ikakari Point Marine Reserve (also known as the Goat Island Marine Reserve) was eventually established in $1977 .^{10}$ Today there are 44 marine reserves all located within New Zealand's territorial sea. ${ }^{11}$ Collectively these marine reserves comprise $17,430 \mathrm{~km}^{2}$, covering about 10 percent of New Zealand's territorial sea or 0.4 percent of New Zealand's territorial sea and EEZ combined. ${ }^{12}$ In addition, New Zealand has proclaimed eight marine mammal sanctuaries and four benthic protection areas. ${ }^{13}$ The benthic protection areas cover the entire territorial seabed surrounding the Antipodes Islands, Bounty Islands and Campbell Island. ${ }^{14}$ In 2015 the New Zealand government announced a proposal to create the Kermandec Ocean Sanctuary covering approximately $620,000 \mathrm{~km}^{2}$ or 15 percent of its EEZ. ${ }^{15}$ Owing to the low level of activity currently taking place in the region, the ocean surrounding the Kermandec islands is relatively pristine. The proposed sanctuary will comprise one of the largest global no-take zones as well as banning seabed-mining activities. ${ }^{16}$

Studies undertaken in New Zealand have demonstrated the role reserves have already played in improving the productivity of biodiversity located within reserves. ${ }^{17}$ For example, over the 20 years since the Tonga Island Reserve was created in Tasman Bay populations of crayfish have increased seven-fold and populations of blue cod over 30 $\mathrm{cm}$ long have increased by a staggering forty-fold. ${ }^{18}$ In a mere decade since the creation of the Horoirangi Marine Reserve numbers of crayfish are 3.5 times higher now than in 2006 and a third of blue cod within the reserve are over $30 \mathrm{~cm}$ in length compared to an average of 1.7 percent outside the reserve. ${ }^{19}$ Moreover, MPAs have important benefits for science, culture, tourism and recreation..$^{20}$ Many current marine reserves now attract thousands of visitors a year and ecotourism in New Zealand is valued at NZ\$8million per annum. ${ }^{21}$ 
Despite these obvious environmental, scientific and economic benefits the history of designating MPAs in New Zealand has been described as "long and complex" benefiting from little clear policy and being managed by multiple agencies and legislative instruments with varied agendas. ${ }^{22}$ In early 2016 the New Zealand government released a consultation document that proposes the creation of a new MPA act, which is designed to rationalise and modernise MPA policy. This article will analyse the proposals in the consultation document and examine the extent to which it will allow New Zealand to meet its international obligations to conserve marine biodiversity and ecosystem function and compare it to best practice in selected other states. The article will conclude with some remarks on the challenges more generally of implementing as opposed to merely creating MPA policy at the national level.

\section{New Zealand's Marine Environment}

New Zealand's maritime zones extend from the sub-tropical waters surrounding Raoul Island $1000 \mathrm{~km}$ north of the mainland to the sub-Antarctic waters surrounding Campbell Island $640 \mathrm{~km}$ south of Bluff. ${ }^{23}$ At over 4 million $\mathrm{km}^{2}$ New Zealand's exclusive economic zone (EEZ) ${ }^{24}$ comprises 15 times the terrestrial land area of New Zealand ${ }^{25}$ and this ratio increases to 21 times the terrestrial area of New Zealand when its extended continental shelf of 1.7 million $\mathrm{km}^{2}$ is included. ${ }^{26}$ Eighty percent of New Zealand's biodiversity is located within its marine environment ${ }^{27}$ and of the 17,135 species described ${ }^{28} 44$ percent are endemic. ${ }^{29}$ Nearly one quarter of the world's seabirds breed in New Zealand and almost 50 percent of the world's cetaceans are found within New Zealand's waters. ${ }^{30}$ New Zealand's varied biodiversity is a consequence of its position at the confluence of subtropical and subantarctic water masses and the presence of rocky coastal reefs, deep ocean trenches and seamounts. ${ }^{31}$ 
New Zealanders have a strong connection to the coast and the marine environment and Māori in particular, value the marine environment for cultural, spiritual and economic purposes. ${ }^{32}$ More generally, marine resources make a significant contribution to New Zealand's economy. Fisheries, which are generally well managed under New Zealand's quota management system, contributed NZ\$1,419 million to exports in 2014. ${ }^{33}$ A similar contribution to exports in 2014 was made by the oil and gas industry, ${ }^{34}$ which generates approximately $\$ 400$ million a year in royalties. ${ }^{35}$

Despite its relative isolation New Zealand's marine environment is far from pristine. More than 25 percent of its indigenous marine mammals are threatened with extinction and the Māui dolphin is critically endangered with only an estimated 55 individuals of more than one year old remaining in the wild. ${ }^{36}$ The incidents of fur seals and sealions being found entangled in plastic in Kaikoura is one of the highest reported in the world, ${ }^{37}$ contributing to a 70 percent decline in sealion populations over approximately 30 years. ${ }^{38}$ Ninety percent of indigenous seabirds breeding in New Zealand are threatened with or at risk of extinction ${ }^{39}$ with bycatch as the most significant albeit now decreasing threat. ${ }^{40}$ Run off from land makes the greatest contribution to marine pollution in New Zealand with 192 million tonnes of soil entering waterways every year. ${ }^{41}$ Remarkably, this level of runoff constitutes 1.5 percent of global sediment loss despite New Zealand comprising only 0.2 percent of global land area. ${ }^{42}$ Land runoff including soil and excess nutrients associated with New Zealand's agriculture industry impacts on water quality and can lead to algal blooms. ${ }^{43}$ In a 2015 report on the state of New Zealand's environment climate change was identified as the most serious long-term threat to the marine environment. ${ }^{44}$ Sea levels have already risen between $1.31 \mathrm{~mm}$ and $2.14 \mathrm{~mm}$ around the coast of New Zealand ${ }^{45}$ and a statistical increase in the acidity of the marine environment in New Zealand's subantarctic has been recorded. ${ }^{46}$ 


\section{Marine Management in New Zealand: An Overview}

In accordance with international law New Zealand exercises sovereignty over its territorial sea ${ }^{47}$ and continental shelf ${ }^{48}$ and, within its exclusive economic zone, exercises sovereign rights for the purposes of the exploitation of living and non-living resources and jurisdiction over the establishment and use of artificial islands, installations and structures, marine scientific research and environmental protection. ${ }^{49}$

The recent history of marine management in New Zealand has been shaped by the long-standing dispute between Māori and the Crown over the status of the foreshore and seabed. In 2003 the New Zealand Court of Appeal overturned legal precedent dating back to $1877^{50}$ and determined that Māori customary title to the foreshore and seabed had not been extinguished by legislation adopted after the 1840 Treaty of Waitangi and that it was open, in principle, for the Māori Land Court to determine the validity of individual claims to the foreshore and seabed..$^{51}$ This decision was almost immediately reversed by the New Zealand government through its adoption of the controversial Foreshore and Seabed Act in 2004, which vested ownership of the foreshore and seabed in the Crown. ${ }^{52}$ The 2004 Act was itself repealed in 2011 by the Marine and Coastal Area (Tukutai Moana) Act, which declared that the foreshore and seabed - referred to for the purposes of the Act as the 'common marine and coastal area (CMCA)' - could not be owned by the Crown or any other person. ${ }^{53}$ Moreover, the 2011 Act restored any customary interest in the CMCA that had been extinguished by the $2004 \mathrm{Act}^{54}$ in addition to creating three new statutory rights to the marine environment: participation in conservation processes; a protected customary use right; and customary title. ${ }^{55}$ This dispute effectively stymied ocean management reform for almost a decade, de-railing plans to develop a New Zealand Oceans Policy ${ }^{56}$ and even impacting on reforms proposed in 2002 for MPA management. It was not until 2012 that legislation was 
adopted for the management of activities taking place in the EEZ ${ }^{57}$ and 2016 that MPA legislative reform has finally been proposed.

The absence of an overarching oceans policy ${ }^{58}$ means that marine management in New Zealand is relatively fragmented between a number of Acts and institutions and, for the most part, bifurcates management between the territorial sea and the EEZ. ${ }^{59}$

Within the territorial sea most activities - with the exception of fishing and oil and gas exploitation - are regulated by the 1991 Resource Management Act (RMA), which has as its overarching purpose the "sustainable management of natural and physical resources." ${ }^{60}$ Management of the coastal and marine environment out to 12 nautical miles is largely devolved to sixteen regional authorities ${ }^{61}$ but must nevertheless comply with overarching national guidance developed by the Minister for Conservation and set out in the 2010 New Zealand Coastal Policy Statement (NZCPS). ${ }^{62}$ Each regional authority must adopt a regional coastal plan, subject to approval by the Minister for Conservation, setting out the principles guiding management of the coastal marine area and the rules relating to individual activities. ${ }^{63}$ Regional coastal plans must comply with the NZCPS and both regional coastal plans and the NZCPS must comply with the principles set out in sections 6,7 and 8 of the 1991 RMA. Section 6 of the RMA identifies matters of national importance that must be provided for in plans, policies and decisions and these include: the preservation of the natural character of the coastal environment; the protection of outstanding natural features and landscapes from inappropriate use and development; the protection of indigenous flora and fauna; the maintenance of public access to the coastal marine area; and the protection of protected customary rights. Section 7 of the RMA identifies additional principles and matters that decision-makers must have regard to including the concepts of stewardship and kaitiakitanga, ${ }^{64}$ the efficient use and development of natural resources, the intrinsic value of ecosystems and the maintenance and enhancement of the natural environment and the 
effects of climate change. In terms of hierarchy, matters identified under section 7 of the RMA are given less weight than the matters of national importance listed under section 6 but they nevertheless comprise an important part of the planning and decision-making context. Finally, decision-makers must consider the principles of the Treaty of Waitangi (Te Tiriti o Waitangi) in relation to management and protection of resources under section 8 of the 1991 RMA. The principal sections of the RMA governing the coastal marine area are 12 and 15 . Section 12 establishes a presumption against any activity (other than fishing or oil and gas exploration, which are regulated under separate legislation) unless that activity is authorised in a regional coastal plan or by a coastal resource consent. Section 15 of the Act manages discharges, dumping and incineration within the territorial sea. The Act sets out detailed provisions relating to the categorisation of activities, the process for obtaining a consent, public participation and review.

The environmental impacts of activities (other than fishing) in New Zealand's EEZ were not subject to regulatory control until 2012 and the adoption of the Exclusive Economic Zone and Continental Shelf (Environmental Effects) Act. The purpose of the Act is consistent with the purpose of the 1991 RMA and comprises the "sustainable management of the natural resources of the exclusive economic zone and the continental shelf" as well as the protection of the marine environment from pollution. ${ }^{65}$ The Act generally prohibits specified activities in the marine environment unless those activities are expressly permitted or authorized by a permit on a case-by-case basis. Prohibited activities include but are not limited to: the construction or placement of structures on or under or activities otherwise disturbing the seabed; discharges from structures or vessels involved in mining operations; dumping; incineration; and burial at sea. ${ }^{66}$ Regulations adopted in 2013, 2014 and 2015 set out activities deemed permitted, discretionary or prohibited (and not able to be authorized by a permit). Activities that are discretionary 
are classified as notified or not notified. ${ }^{67}$ Activities that are discretionary may be authorized by a marine consent issued by the Environmental Protection Authority (EPA). ${ }^{68}$ The Act sets out detailed procedures relating to environmental impact assessment, public participation and the factors that must be taken into account by the EPA. These include the impact of the activity on the marine environment, the importance of protecting species and ecosystems and the economic benefit to New Zealand. ${ }^{69}$ The Act endorses the precautionary principle as well as adaptive management where information is uncertain. ${ }^{70}$ The 2012 Act provides for review and appeal as well as detailed enforcement provisions.

Within New Zealand's entire maritime zone other activities are subject to designated legislative regimes including shipping (primarily regulated under the 1994 Maritime Transport Act), fishing (subject to the 1996 Fisheries Act) and oil and gas activities (subject to the Crown Minerals Act 1991). Moreover, legislation has been adopted to protect marine species (such as the 1978 Marine Mammals Protection Act, 1953 Wildlife Act and 1989 Trade in Endangered Species Act) as well as particular threats (for example the 1993 Biosecurity Act). At least six government ministries have responsibility for marine matters in addition to regional and local agencies and bodies. This complex picture of marine management in New Zealand generally is more specifically reflected in the current regulatory framework for marine protected areas and one important motivation for the reforms proposed in 2016 is to simplify and streamline the process of MPA designation and management.

\section{Evolution of MPA Management in New Zealand}

The primary instrument for MPA designation within the current legal framework is the 1971 Marine Reserves Act, which permits reserves to be established within New 
Zealand's internal waters or territorial sea ${ }^{71}$ in order to preserve areas for the purpose of scientific study. ${ }^{72}$ Areas suitable for reserve status comprise those that "contain underwater scenery, natural features, or marine life, of such distinctive quality, or so typical, or beautiful, or unique, that their continued preservation is in the national interest." 73 The objectives of reserve designation are to preserve the areas as far as possible in their natural state, protect and preserve the marine life and their habitats therein and as far as possible, to preserve public freedom of access to the reserves for the purpose of studying, observing, and recording marine life in its natural habitat. ${ }^{74}$ Marine reserves provide for the highest level of protection in New Zealand's waters and prohibit fishing ${ }^{75}$ as well as mining. ${ }^{76}$ Marine reserves under the Act are declared by an Order in Council on the application of a limited number of entities including universities, bodies administering land under the 1977 Reserves Act located on the coast, bodies engaged in the scientific study of marine life or natural history, Māori iwi or hapu who have tangata whenua status over the area and the Director-General of Conservation. All marine reserves are subject to a conservation management plan $^{77}$ and the management of activities including diving, anchoring, navigation and the exclusion of the public from areas closed for scientific study is addressed in the 1993 Marine Reserves Regulations (SR 1993/230).

MPA objectives not associated with marine scientific research may be achieved using other legislative instruments. For example, the conservation of biodiversity is primarily managed through the creation of marine mammal sanctuaries designated by the Minister for Conservation under the Marine Mammals Protection Act $1978^{78}$ and the temporary or permanent closure of areas to fisheries by the Minister for Primary Industries under the 1996 Fisheries Act. ${ }^{79}$ Both Acts apply to New Zealand's territorial sea and EEZ. Fisheries can also managed through temporary closure under customary law using the concepts of rāhui, mātaitai and taiāpure. ${ }^{80}$ In theory, sanctuaries established 
under the 1953 Wildlife Act can extend into the marine area, ${ }^{81}$ but this option has yet to be utilised. The protection of vulnerable areas from the impacts of shipping within New Zealand's entire maritime zone is addressed through the declaration of 'areas to be avoided' by the Ministry of Transport under the 1994 Maritime Transport Act. ${ }^{82}$ Management of a wider range of activities for the purpose of environmental protection within the territorial sea is governed by the 1991 Resource Management Act, which permits regional councils to identify areas in need of protection within their regional coastal plans and to specify activities (excluding fishing and mining) that are prohibited or subject to restriction. ${ }^{83}$ Within the EEZ or on the continental shelf areas classified as important or vulnerable owing to their biophysical characteristics or for specific uses or which are subject to multiple uses or management regimes can be closed to a range of activities including discharges, dumping, construction or disturbance of the seabed under section 28 of the 2012 Exclusive Economic Zone and Continental Shelf (Environmental Effects) Act. The protection of seabed infrastructure such as cables and pipelines is primarily addressed through the designation of protected areas under the Submarine

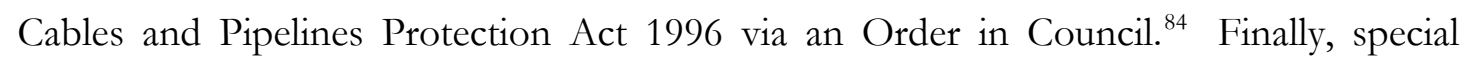
legislation can be adopted in order to designate MPAs and this option has been used relatively extensively over the last decade to establish MPAs and, on occasion, management authorities, in the Hauraki Gulf, ${ }^{85}$ Fiordland, ${ }^{86}$ Kaikōura, ${ }^{87}$ the subantarctic islands ${ }^{88}$ and the Sugar Loaf Islands. ${ }^{89}$ The level of protection varies within these MPAs but typically mining is prohibited, fishing is prohibited or restricted and, in some cases, recreational activities are subject to strict management.

In order to respond to its obligations under the 1992 Biological Diversity Convention $^{90}$ and in particular the 2012 MPA target, the New Zealand government in 2005 adopted the Marine Protected Areas Policy and Implementation Plan (the Policy). ${ }^{1}$ The objective of the Policy is the protection of marine biodiversity through the creation of a 
network of MPAs that is comprehensive and representative of New Zealand's marine habitats and ecosystems. ${ }^{92}$ For the purposes of the Policy a MPA is defined as "[a]n area of the marine environment especially dedicated to, or achieving, through adequate protection, the maintenance and/ or recovery of biological diversity at the habitat and ecosystem level in a healthy functioning state." 93 The Policy, which applies to New Zealand's territorial sea and EEZ, ${ }^{94}$ seeks to facilitate the development of a network of MPAs through coordinating the implementation of existing legislative and administrative tools and establishing a set of implementation and planning principles. ${ }^{95}$ These principles require that: the MPA network is representative and designated on a consistent approach to habitat and ecosystem classification based on the best scientific information; that management tools must be sufficient to meet the protection standard of each site and the overall viability of the network; that designation of MPAs is guided by a precautionary approach; that the special relationship between the Crown and Māori be recognised and the process of MPA designation be more generally undertaken in a manner which is transparent, participatory, timely and which minimises adverse impacts on existing users; that provision is made for the evaluation, monitoring and adaptive management of MPAs; and that the regime is enforceable. ${ }^{96}$ The potential for conflict between some of these principles is evident - such as the need to base decisions on best scientific information as well as applying the precautionary approach and the requirement to provide for sufficient environmental protection whilst minimising adverse impacts on marine users - but the Policy provides little advice on mechanisms to resolve potential conflicts. Moreover, the (then) Ministry of Fisheries (now Ministry of Primary Industries) and the Department of Conservation are charged with jointly administering the MPA Policy ${ }^{97}$ notwithstanding their very different mandates and constituencies.

Further guidance issued in $2008^{98}$ identified fourteen biogeographic regions to provide the basis of planning the MPA network ${ }^{99}$ and confirmed that the MPA Policy 
will be implemented on a regional basis through community-based Marine Protection Planning Forums (MPPF). ${ }^{100}$ The MPPF, which, incidentally, do not entirely coincide with the regional authorities more generally responsible for managing activities with the territorial sea under the 1991 RMA, comprise 14 members including representation from industry and local interest groups with representatives from the Department of Conservation and Ministry of Primary industries as ex officio members. ${ }^{101}$ Each MPPF will provide recommendations for MPAs within their region. ${ }^{102}$ The Guidelines divide MPAs into two categories: Type 1 MPAs comprise marine reserves so designated under the 1971 Marine Reserves Act; Type 2 MPAs comprise protected areas designated under any other legislative instrument. The Guidelines also clarified that the MPA Policy would apply to the territorial sea only until $2013 .{ }^{103}$

Progress in designating MPAs in New Zealand waters has been slow. A gap analysis conducted in 2011 concluded that with the exception of the Kermandecs and subantarctic there are significant MPA gaps in other bioregions. ${ }^{104}$ Fundamentally, New Zealand lacks a firm legislative basis from which to implement the MPA Policy. The primary legislative instrument - the 1971 Reserves Act - has led to an emphasis on the protection of small iconic sites around the mainland at the expense of creating a network of biologically representative areas. ${ }^{105}$ The objective of the 1971 Act, which is to protect sites for the purposes of scientific study rather than conservation, is now inconsistent with modern MPA management, and the function of MPAs under this and indeed other legislation has been largely confined to narrowly managing the effects of fishing. ${ }^{106}$ The process of MPA designation under both primary legislation and the MPA Policy requires collaboration between the Department of Conservation and the Ministry of Primary Industries, which is responsible for fisheries, and this has led to significant conflict. "Rather than seeing marine reserves as part of ocean sustainability they have been viewed as impeding the potential for utilisation of resources." ${ }^{\text {"107 }}$ Additionally, MPA proposals 
typically generate a significant level of opposition from commercial and recreational fishers ${ }^{108}$ and, on occasion, iwi. It is notable that the 1971 Reserves Act contains no reference to the 1840 Treaty of Waitangi or its principles and provides for very limited participation of Māori and iwi. ${ }^{109}$ Combined with a general absence of political leadership in this area ${ }^{110}$ these factors have contributed to the extended period over which MPAs are typically established in New Zealand. Twelve years elapsed from the date of its proposal before New Zealand's first marine reserve, Goat Island, was established. ${ }^{111}$ It took seventeen years to establish the Taputeranga reserve ${ }^{112}$ and twentyone years to provide for comprehensive protection in the subantarctic. ${ }^{113}$ Although in more recent years the government has resorted to special legislation to designate MPAs this ad hoc approach reduces opportunities to consider sites as part of a representative network or indeed to integrate MPAs into broader ocean management.

\section{The 2016 MPA Reform Proposals}

The first set of MPA reform proposals were released in 2002 through the Marine Reserves Bill. The Bill was designed to support the implementation of the New Zealand Biodiversity Strategy adopted in $2000^{114}$ and to provide a legislative basis for designating MPAs for the purpose of protecting marine ecosystems within New Zealand's entire maritime zone. As noted above, the Bill and ocean management reform more generally, became a victim of the dispute between the Crown and Māori over the status of the seabed and the Bill was eventually abandoned and replaced, in part, with the 2005 MPA Policy. It took a further fourteen years for revised proposals to be produced but in January 2016 the Ministry of the Environment released a consultation document proposing a new marine protected areas act. ${ }^{115}$ 
The aim of the proposed MPA act is to contribute to a marine management system designed "to achieve an appropriate balance between protecting [the] marine environment and maximising commercial, recreational and cultural opportunities now and in the future." 116 More specifically, the act will facilitate the creation of a representative and adaptable network of MPAs within New Zealand's territorial sea designed to enhance, protect and restore marine biodiversity. ${ }^{117}$ Addressing the particular shortcomings of the 1971 Marine Reserves Act with respect to process, the proposed new MPA act will expressly recognise Māori customary rights and values in the marine environment and will ensure that the Crown's obligations under the 1840 Treaty of Waitangi are met. ${ }^{118}$ Under the proposed MPA act four categories of MPA are developed: marine reserves; species-specific sanctuaries; seabed reserves; and recreational fishing parks. $^{119}$

Marine reserves will benefit from the highest level of protection with fishing and minerals activities banned therein. The purpose of a marine reserve is to preserve unique or special areas as well as representative sites that exemplify important ecosystem features and values in their natural state. ${ }^{120}$ The 44 marine reserves already established under the 1971 Marine Reserves Act will transition into the new MPA act with no changes to their level of protection or their existing legislative base where they have been established using special legislation. ${ }^{121}$ The 1971 Marine Reserves Act will be repealed ${ }^{122}$ but the lead agency charged with designating and managing marine reserves remains the Department of Conservation.

Species-specific sanctuaries will be established to protect and preserve named species while allowing for their sustainable use. ${ }^{123}$ Species-specific sanctuaries will be designated to protect marine mammals but can also be adopted for the protection of other species such as albatross, great white sharks and coral. ${ }^{124}$ The level of protection within species-specific sanctuaries will vary according to ecological imperative and local 
community preferences. ${ }^{125}$ Sanctuaries established under the 1978 Marine Mammals Act, the 1953 Wildlife Act as well as the whale and New Zealand fur sea sanctuary established under the Kaikōura (Te Tai o Marokura) Marine Management Act 2014 will all transition into the new MPA Act. ${ }^{126}$ The lead agency for species-specific sanctuaries will be the Department of Conservation. ${ }^{127}$

Seabed reserves will be designed to protect and manage the sustainable use of benthic ecosystems, and activities impacting on the seabed such as mining, bottom trawl fishing and dredging will be prohibited therein. ${ }^{128}$ There is currently no general protection for the seabed provided for in legislation but the 1996 Fisheries Act does provide for benthic protection areas and seamount closures and these sites will be assessed as potential candidates for seabed reserves. ${ }^{129}$ The Ministry for the Environment has been designated the lead agency for seabed reserves. ${ }^{130}$

Finally, recreational fishing parks will be established to "enhance the enjoyment and value of recreational fishing in high-demand areas". ${ }^{131}$ Commercial fishing for the primary recreational species within these parks will be prohibited but customary fishing will be permitted to continue. Marine farming will be unaffected, as will minerals activities. ${ }^{132}$ Existing fishing parks, such as Mimiwhangata Marine Park and Sugar Loaf Islands Marine Protected Area will be transitioned into the new MPA act ${ }^{133}$ and unsurprisingly, the Ministry for Primary Industries has been designated the lead agency for creating and managing recreational fishing parks. ${ }^{134}$ In a departure from current practice, which makes no provision for financial compensation in areas closed to fisheries, the MPA act will permit, in principle, the compensation of commercial fishers whose quota has been significantly impacted by the creation of a recreational fishing park. ${ }^{135}$ Compensation will not be payable where commercial fishing is prohibited in marine reserves, species-specific sanctuaries or seabed reserves. ${ }^{136}$ The consultation document proposes that the MPA act create two new recreational fishing parks: the 
Hauraki Gulf Recreational Fishing Park and the Marlborough Sounds fishing park. ${ }^{137}$ The Hauraki Gulf supports the largest recreational snapper fishery in New Zealand and up to 6900 recreational vessels carrying 21,000 fishers may be operating on any one day in the height of summer. ${ }^{138}$ By contrast, the Marlborough Sounds supports a large recreational blue cod fishery, which owing to significant pressure, was fully closed between 2009 and 2011 and is now subject to tight catch restrictions. ${ }^{139}$ In both parks it is proposed that commercial restrictions apply to a limited number of species including snapper and blue cod with other species being available to commercial fishers through the quota system. ${ }^{140}$

The new MPA act as currently envisaged will provide for a much more consultative and collaborative process for the designation of MPAs in striking contrast to the much criticised mechanism currently in operation under the 1971 Reserves Act. In order to identify areas appropriate for MPA designation the government will draw on marine ecosystem research currently being undertaken in a NZ\$31.3million marine science project entitled Sustainable Seas National Science Challenge. ${ }^{141}$ The act will include criteria for the designation of each category of MPA and proposals will only advance if they adequately describe the benefits to the environment of protection and assess the economic impacts on both current and future uses. ${ }^{142}$ Initial MPA proposals are made to the lead minister (depending on the category of the MPA) and if the Minister accepts the proposal in principle he/ she must consult with other ministries and various interested parties. The ministers for Conservation, Primary Industries, Environment and Māori Development will be automatically involved in every proposal. ${ }^{143}$ If the ministers decide that a proposal should be advanced the process of extensive consultation begins. The MPA act provides for two options for consultation. ${ }^{144}$ First, a self-governing collaborative process involving all interested parties including fishers, iwi, local community and industry operating under the terms of reference determined by the 
relevant Minister. Once consensus has been achieved through the self-governing collaborative process a recommendation to establish/ not establish a MPA is made to the relevant Ministers. ${ }^{145}$ The second option is the referral of the proposal to a Board of Enquiry, chaired by a judge and comprising representative persons appointed by the relevant Minister. ${ }^{146}$ The Board must assess the proposal against the terms of reference as set out by, and make a final recommendation to, the Minister. Under both processes the proposal must be assessed in relation to: the costs and benefits to the environment and to the economy; the likely contribution of the MPA to the creation of a representative and adaptable network of MPAs; current levels of protection and existing and future uses; the effect on Treaty of Waitangi rights and obligations; and its contribution to New Zealand's international commitments. ${ }^{147}$ If the first option, the selfgoverning collaborative process, is unable to achieve consensus the relevant Minister can refer the proposal to a Board of Enquiry. ${ }^{148}$ On receipt of the recommendation by either process the relevant Minister can choose to accept or reject the recommendation or refer it back for reconsideration or amendment but the Minister cannot unilaterally change any recommendation made. ${ }^{149}$

The purpose of the proposed new MPA act is the protection of marine biodiversity. The act is not intended to effect protected areas established under other legislation such as the 1994 Maritime Transport Act and the 1996 Submarine Cables and Pipelines Act to manage the impacts of shipping and the protection of seabed infrastructure respectively. The act will however, impact on the management of marine activities by regional authorities. In order to align decision-making, the new MPA act will require the four categories of MPAs to be recognised in regional coastal plans. ${ }^{150}$ The process of marine consents under section 12 of the 1991 RMA will continue to apply to activities taking place within MPAs but the existence of the MPA is a relevant consideration for decision-makers when considering a consent application. Moreover, 
the MPA act will acknowledge the role already played by a number of management boards in regions such as Fiordland, Kaikōura and South East Otago and seek to support the integrated management of the marine environment in these areas. ${ }^{151}$ Finally, the proposed act will provide for periodic review of MPAs and the consultation document outlines a number of options including: making review a condition of MPA designation; permitting review in the event of a significant change in circumstances such as the discovery of a new resource; or a generational review "to recognise that the Māori view that decisions made by contemporary generations should not tie the hands of future generations."

\section{Critique of the 2016 MPA Reform Proposals}

The first criticism of the 2016 MPA reform proposals relates to scope. The new MPA act is deliberately designed to apply to just four percent of New Zealand's maritime zone: the territorial sea. Although the consultation paper attempts to justify this restriction on the basis that it is within 12 nautical miles of the coast that risks to biodiversity are greatest and that most competing activities are located, ${ }^{153}$ this decision is significantly out of step with international policy and practice in other jurisdictions, such as Australia, ${ }^{154} \mathrm{Canada}^{155}$ and the UK, ${ }^{156}$ all of which provide for MPA designation within their EEZs. As such, the proposed act is not sufficient to support New Zealand's obligations under the 1992 Biodiversity Convention, in particular, in achieving Aichi Biodiversity Target 11, that requires 10 percent of the marine environment to be protected by 2020. New Zealand may attempt address this deficiency in scope by designating MPAs in its EEZ on an ad hoc basis by means of special legislation, the first of which is slated for adoption in 2016 in order to create the Kermandec Ocean Sanctuary. Ad hoc MPA designation however, is unlikely to properly contribute to New 
Zealand's international obligation to create an "ecologically representative and well connected [system] of protected areas", ${ }^{157}$ a fact already recognised by the New Zealand government in relation to the current ad hoc process of MPA designation within the territorial sea and used by the government as a justification for the current reform proposals. ${ }^{158}$ The MPA act as proposed represents an important missed opportunity to develop general principles and processes for the designation of MPAs within New Zealand's entire maritime zone. Furthermore, the announcement that separate ad hoc legislation to establish the Kermandec Ocean Sanctuary is due for debate and adoption in the same year as the proposed MPA act demonstrates the incoherency in current government policy.

Second, although the four categories of MPAs undeniably broaden the current scope of area protection and much more strongly endorse the purpose of biodiversity conservation, their roots remain firmly embedded in the current, now out of date practice of strictly protecting small iconic sites or protecting larger areas from a single or narrow range of threats. By contrast, other states regarded as leaders in marine management, have adopted the best practice of designating larger MPAs designed to integrate the management multiple activities. Australia was one of the first states to do this with the establishment of the Great Barrier Reef Marine Park by legislation in 1975. ${ }^{159}$ The Act provides for the management of multiple activities including fishing, tourism and extractive industries according to their impact utilising zoning as a management technique. ${ }^{160}$ More generally, Commonwealth reserves designated under s344 of the Environment Protection and Biodiversity Conservation Act 1999 can be used to manage and control a wide range of activities. ${ }^{161}$ Multifunctional MPAs have also been developed in Canada ${ }^{162}$ and in the UK. ${ }^{163}$ Despite the various references to integrated management within the MPA consultation paper and the concession that whilst marine reserves comprise a complete protection tool the other three MPA options could overlap 
and thereby collectively provide for more comprehensive protection, ${ }^{164}$ the proposals do not permit the designation of genuine integrated multiple use protection zones. Moreover, because the proposed MPA act is confined to the territorial sea it fails to provide for area protection or buffer zones that extend into the EEZ. The act does address the alignment of decisions relating to activities taking place within or adjacent to MPAs by regional councils within the territorial sea but is silent on the relevance of MPAs to decision-makers authorising activities within the EEZ. As noted above however, the factors which must be considered by the EPA when considering a consent application under the 2012 Exclusive Economic Zone and Continental Shelf (Environmental Effects) Act include other applicable law and effects on activities not regulated under the Act, ${ }^{165}$ both of which are broad enough to cover MPAs established under the proposed act (and other legislation).

Third, the consultation document as released omits discussion of certain core environmental principles. In articulating the objectives of the proposed MPA act the document refers to the protection and preservation of marine biodiversity ${ }^{166}$ and its purpose, to establish a representative and adaptable network of MPAs, implies the application of an ecosystem approach. ${ }^{167}$ Principles relating to collaboration, community engagement and, particularly, respect for Māori rights and values are strong. ${ }^{168}$ However, economic growth, the desire to maximise benefit to New Zealand and to protect existing and future uses and values are also listed as objectives of the proposed act ${ }^{169}$ and each proposal must be subject to an economic assessment as to its potential impacts. ${ }^{170}$ There is no clear reference to the precautionary principle and the process of designation proposed by the act relies heavily on a scientific case being made for the MPA, a case furthermore, which is weighed up against an economic assessment of its benefits. Moreover, there is no express reference to the interests of future generations. 


\section{Concluding Remarks}

The proposed new MPA act represents an important step in modernising New Zealand's approach to MPA designation and reflects the emerging importance of MPAs as a core ocean management tool in New Zealand. ${ }^{171}$ Most importantly, the proposed act will provide a clear legal basis for designating MPAs for the purpose of biodiversity conservation as opposed to for scientific research or fisheries management. The proposed act will also provide for a much more comprehensive and collaborative process of consultation with active and meaningful involvement of local communities, Māori and iwi as well as industry designed to reduce local opposition to the designation of MPAs. This process undoubtedly supports New Zealand's obligation to provide for effective and equitable management of MPAs ${ }^{172}$ and seeks to address the long-standing challenge of managing often-competing conservation, social and economic interests. ${ }^{173}$ Furthermore, the current potential for and, at times, actual conflict between the Department of Conservation and the Ministry of Primary Industries is likely to be better managed under the new act as a lead agency is designated in respect of each category of reserve although a more ambitious solution would have been to have designated one agency to manage the entire MPA network. On the other hand as the proposed act stands, it represents something of a lost opportunity. Restricting its application to New Zealand's territorial sea, a mere four percent of New Zealand's maritime zone arguably precludes New Zealand from meeting its international obligation to create a network of well connected MPAs with special emphasis on those of particular importance for biodiversity and ecosystem services by 2020. ${ }^{174}$ Moreover, whilst it partially integrates with broader management of activities within the territorial sea the proposed act nevertheless supports the maintenance of multiple unconnected agencies managing separate activities within New Zealand's maritime zone. 
Balancing the various competing interests associated with MPA designation is however, no easy task as demonstrated globally by the slow rate of ocean protection in contrast to terrestrial protected areas. Even those states that provide for a much more comprehensive and robust system of area protection on paper have encountered challenges in its implementation. For example, although the government in England and Wales tasked one agency to manage the overall coordination of the MCZ network ${ }^{175}$ and a consultative exercise not unlike the one envisaged in the proposed MPA act was initiated in 2008, resulting in 127 recommended MCZ sites, only 27 such sites were designated in 2013 with a further 23 sites designated in early 2016. ${ }^{176}$ The $50 \mathrm{MCZs}$ designated cover $20,700 \mathrm{~km}^{2}$ or around 20 percent of English waters but thus far are largely "paper parks" with little or no active management. ${ }^{177}$ These MPAs around the British mainland can be contrasted unfavourably with the highly precautionary large notake zones surrounding Britain's overseas territories including Ascension Island, the Chagos Archipelago and Pitcairn Island. In Australia, a network of 40 MPAs covering over 2 million $\mathrm{km}^{2}$ was proclaimed in $2012^{178}$ as the culmination of a process initiated in 1998 to develop a National Representative System of marine Protected Areas (NRMSPA) by the Commonwealth, states and the Northern Territory. Despite extensive planning, supported by the development of a spatial framework classifying Australian waters into 41 provincial bioregions, and consultation - around 80,000 submissions on the proposed network were received ${ }^{179}$ - following a change of government, the Governor-General in 2013, re-proclaimed the network, ${ }^{180}$ removing the management plans, which were due to enter into force in July 2014 for all but one of the bioregions. ${ }^{181}$ The Australian coalition government subsequently initiated a Commonwealth Marine Reserves Review, comprising two streams designed to review the science supporting the MPA network and to facilitate enhanced consultation with stakeholders. ${ }^{182}$ The Review was due to report by the end of 2015 but at the time of writing no public report has been 
released. Without active management plans these reserves are, like their British counterparts, for the time being paper parks.

It remains to be seen whether the much less ambitious strategy proposed by New Zealand, pragmatically limiting both the geographical and functional scope of MPA management ultimately proves more successful, at least in the short term, than the pioneering and principled but troubled networks in the process of being developed by the UK and Australia. There are potential advantages for developing ocean protection on an incremental basis but there are also risks, particularly where that protection is being developed in the absence of an overall oceans policy or strategy. The very slow pace of developing ocean environmental management in New Zealand, particularly in relation to area protection, suggests that if the MPA act is adopted as proposed, comprehensive area protection within New Zealand's entire maritime zone will not be achieved by 2020 and principle will be sacrificed for pragmatism.

\footnotetext{
- Professor of Law, University of Canterbury. This article is part of a broader project on ocean governance in New Zealand supported by the New Zealand Law Foundation. The author would like to acknowledge the Foundation for their support associated with the research of this article.

${ }^{1}$ Nigel Dudley (ed), Guidelines for Applying Protected Area Management Categories (Best Practice Protected Area Guidelines Series No. 21 at 2.

2 Ibid at 8 .

${ }^{3}$ Jane Lubchenco and Kirsten Grorud-Colvert, "Making waves: The science and politics of ocean protection" 359 (23 October 2015) Science $382-383$ at 382.

${ }^{4}$ See Juffe-Gignoli D, Burgess ND, Bingham H et al, Protected Planet Report 2014. Tracking progress towards global targets for protected areas (UNEP-WCMC: Cambridge UK, 2014) at 7.

${ }^{5}$ Convention on Biological Diversity, COP 10 Decision X/2 Strategic Plan for Biodiversity (2010). This target replaces the original deadline of 2012 agreed in 2002 at the World Summit on Sustainable Development (WSSD) (see WSSD, Plan of Implementation (2002) at para. 31(c)) and endorsed by the parties to the 1992 Convention on Biodiversity in 2004. See CBD COP 7 Decision VII/28 Protected Areas (Articles 8(a) to (e)) para. 18; CBD COP 7 Decision VII/ 5 Marine and coastal biodiversity, paras. 18-31 and CBD COP 7 Decision VII/30 Strategic Plan: future evaluation of progress, Annex II, Goal 1.1.

${ }^{6}$ For an overview of the changing approaches to MPA management see Mark D Spalding, Imèn Meliane, Amy Milam et al, "Protecting Marine Spaces: Global Targets and Changing Approaches" 27 (2013) Ocean Yearbook $213-248$.

${ }^{7}$ Nigel Dudley (ed), op cit n. 1 at 55 and Mark D Spalding, Imèn Meliane, Amy Milam et al, ibid, at 240. 8 A coastal state's rights and responsibilities within the water column are limited to an area 200 nautical miles beyond the baseline (1982 United Nations Convention on the Law of the Sea (UNCLOS), Articles 56 and 57). By contrast a coastal state's rights over the seabed may extend beyond this, up to 350 nautical miles or further where it claims an extended continental shelf (UNCLOS, Articles 76 and 77).

${ }_{9}^{9}$ Bill Ballantine, "Fifty years on: Lessons from marine reserves in New Zealand and principles for a worldwide network" 176 (2014) Biological Conservation 297 - 307 at 298.

${ }^{10}$ Lucy Brake and Rawwyn Peart, Sustainable Seas. Managing the Marine Environment (EDS, Auckland, 2015) at 133 .
} 
${ }^{11}$ Ministry for the Environment and Statistics New Zealand, New Zealand's Environmental Reporting Series: Environment Aotearoa 2015 (Ministry for the Environment, Wellington, 2015) (hereinafter, Environment Aotearoa 2015) at 92. For details on New Zealand's marine reserves see: http://www.doc.govt.nz/marinereserves. See also Janet Hunt, Our Big Blue Backyard. New Zealand's Oceans and Marine Reserves (Random House, Auckland, 2014).

${ }^{12}$ Environment Aotearoa 2015 at 92.

${ }^{13}$ Ministry for the Environment, A New Marine Protected Areas Act: Consultation Document (2016) at 12 (hereinafter, MPA Consultation Document (2016)) available at www.mfe.govt.nz.

14 Ibid.

${ }^{15}$ See http://www.theguardian.com/world/2015/sep/29/new-zealands-new-ocean-sanctuary-will-be-oneof-worlds-largest-protected-areas.

${ }^{16}$ MP A Consultation Document (2016) at 9.

17 As will be discussed below, the purpose of marine reserves under the primary MPA instrument, the 1971 Marine Reserves Act is to preserve areas in their natural state for scientific study. Since the creation of the first marine reserve in 1975, 167 peer review publications have been produced relating to research associated with reserves in addition to 136 university theses and 170 unpublished reports. Source: http://www.doc.govt.nz/Documents/conservation/marine-and-coastal/marine-protectedareas/monitoring-factsheets/scientific-research-marine-monitoring.pdf.

18 MPA Consultation Document (2016) at 18.

19 Ibid.

${ }^{20}$ Lucy Brake and Rawwyn Peart, op cit. n 10 at $117-120$.

${ }^{21}$ Mark J. Costello, "Long live Marine Reserves: A review of experiences and benefits" 176 (2014) Biological Conservation $289-296$ at 290.

22 Bill Ballantine, op cit $\mathrm{n} 9$ at 298.

${ }^{23}$ Dennis P Gordon et al, 'Marine Biodiversity of Aotearoa New Zealand' 5(8) (2010) PLoS ONE e10905 at 1.

${ }^{24}$ Source: Land Information New Zealand - http://www.linz.govt.nz/about-linz/what-weredoing/projects/new-zealand-continental-shelf-project/map-continental-shelf.

25 Dennis P Gordon et al, op cit n 23 at 1.

${ }^{26}$ Source: Land Information New Zealand - http://www.linz.govt.nz/about-linz/what-weredoing/projects/new-zealand-continental-shelf-project/map-continental-shelf.

${ }^{27}$ Ministry for the Environment, Environment New Zealand 2007 (Ministry for the Environment, Wellington 2007) (hereinafter, Environment New Zealand 2007) p. 316.

${ }^{28}$ Dennis P Gordon et al, op cit n 23 at 1

${ }^{29}$ Environment New Zealand 2007 at 316.

${ }^{30}$ Environment Aotearoa 2015) at 93.

31 Ibid.

32 Ibid at 93. Māori own approximately 40 percent of the commercial fishing quota.

33 Ibid at 92.

${ }^{34}$ Ibid at 93 . The value of oil and gas exports in 2014 was NZ\$1,400 million.

35 Ibid.

36 Ibid at 97.

${ }^{37}$ Ibid at 100 .

38 Ibid at 97.

${ }^{39}$ Ibid at 102.

${ }^{40}$ Ibid at 97 . Between 2001 and 2014 an estimated 55,000 seabirds were caught in fishing gear as bycatch.

41 Ibid at 99.

42 Ibid.

${ }^{43}$ Ibid.

44 Ibid at 94.

45 Ibid at 95 .

46 Ibid at 94.

471982 UNCLOS, Article 2.

481982 UNCLOS, Article 77.

491982 UNCLOS, Article 56.

${ }^{50}$ Wi Parata v. Bishop of Wellington (1877) 3 NZ Jur (NS) (SC). See also Re Ninety Mile Beach [1963] NZLR 461 (CA).

51 Attorney General v. Ngati Apa [2003] 3 NZLR 643 (CA).

52 On the foreshore and seabed debate see David Grinlinton, "Private Property Rights versus Public Access: The Foreshore and Seabed Debate" 7 (2003) New Zealand Journal of Environmental Law 313; Jacinta 
Ruru, "The Political and Juridical Battle in the Salt-sand Environment" in Jacinta Ruru, Janet Stephenson and Mick Abbott (eds), Making our place: exploring land-use tensions in Aotearoa New Zealand (Otago University Press, Otago) (2011) 23.

532011 Marine and Coastal Area (Tukutai Moana) Act, section 11(2).

542011 Marine and Coastal Area (Tukutai Moana) Act, section 6.

552011 Marine and Coastal Area (Tukutai Moana) Act, sections 47 - 50, 51, 58 - 50. See generally, Abby Suszko, "The Marine and Coastal Area (Takutai Moana) Act 2011: A Just and Durable Solution to the Foreshore and Seabed Debate?” 25 (2012) New Zealand Universities Law Review 148 - 179.

${ }^{56}$ See Derek Nolan (ed), Environmental and Resource Management Law (LexisNexis, Wellington) (2011) at 5.97.

${ }^{57}$ Exclusive Economic Zone and Continental Shelf (Environmental Effects) Act 2012.

${ }^{58}$ For background to the abandoned attempt to develop a formal oceans policy see Patrick, "All at Sea: Do We need an Oceans Policy for New Zealand” IX (2001) Resource Management Journal 1 - 5.

${ }^{59}$ See generally Lucy Brake and Rawwyn Peart, op cit. n 10; Derek Nolan (ed), op cit n 56 chapters 5 and 9; Peter Salmon and David Grinlinton, Environmental Law in New Zealand (Thompson Reuters, Wellington) (2015) chapter 14.

${ }^{60} 1991$ Resource Management Act, section 5.

${ }^{61}$ With respect to New Zealand's offshore islands in the subantarctic and Pacific the Ministry of Conservation is charged with the equivalent functions as a regional authority with respect to planning and decision-making.

621991 Resource Management Act, sections 57 and 58. The latest NZCPS was adopted in 2010 and is available at: http://www.doc.govt.nz/documents/conservation/marine-and-coastal/coastalmanagement/nz-coastal-policy-statement-2010.pdf.

631991 Resource Management Act, sections 57, 58, 64 and Schedule 1.

${ }^{64}$ Kaitiakitanga is defined for the purposes of the 1991 RMA as "the exercise of guardianship by the tangata whenua of an area in accordance with tikanga Maori in relation to natural and physical resources; and includes the ethic of stewardship" (section 2).

652012 Exclusive Economic Zone and Continental Shelf (Environmental Effects) Act, section 10(1).

${ }^{66}$ Ibid, sections $20-20 \mathrm{~J}$.

${ }^{67}$ Exclusive Economic Zone and Continental Shelf (Environmental Effects_-Permitted Activities) Regulations 2013 (SR 2013/283); Exclusive Economic Zone and Continental Shelf (Environmental Effects-Non-notified Activities) Regulations 2014 (SR 2014/43); Exclusive Economic Zone and Continental Shelf (Environmental Effects-Discharge and Dumping) Regulations 2015 (SR 2015/228); Exclusive Economic Zone and Continental Shelf (Environmental Effects—Burial at Sea) Regulations 2015 (SR 2015/229).

682012 Exclusive Economic Zone and Continental Shelf (Environmental Effects) Act, section 38.

${ }^{69}$ Ibid, section 59.

70 Ibid, section 34(2) and (3).

711971 Marine Reserves Act, section 2.

72 Ibid, section 3(1).

73 Ibid.

74 Ibid, section 3(2).

75 Ibid, section 3(3). Fishing activities can be authorized by the Minister of Conservation (section 3(3) (a) -

(c) but this permission has been rarely exercised.

761977 Crown Minerals Act, section 61 and Schedule 4.

771971 Marine Reserves Act, sections 7 and 8.

781978 Marine Mammals Act, section 22.

791996 Fisheries Act, sections 186A and 311.

${ }^{80}$ See further, Peter Salmon and David Grinlinton, op cit n 59 at 8.6.1.

811957 Wildlife Act, section 9.

821994 Maritime Transport Act, section 36.

831991 Resource Management Act, sections 64, 67 and Schedule 1.

${ }^{84}$ Submarine Cables and Pipelines Protection Act 1996, section 12.

85 The Hauraki Gulf Marine Park Act 2000 established the Tawharanui Marine Park as well as the Hauraki Gulf Forum.

86 The Fiordland (Te Moana o Atawhenua) Marine Management Act 2005 establishes Fiordland (Te Moana o Atawhenua) Marine Area and the Fiordland Marine Guardians. The eight marine reserves established under the Act are deemed to be marine reserves under section 4(1) of the Marine Reserves Act 1971 and the terms of the Marine Reserves Act apply to those reserves (section 8 of the 2005 Act).

${ }^{87}$ The Kaikōura (Te Tai o Marokura) Marine Management Act 2014 establishes Te Whata Kai o Rakihouia I Te Tai o Marokura/ Kaikōura Marine Area as well as the Kaikōura Guardians. Within the marine area a 
number of zones have been designated including a marine reserve, a fur seal sanctuary, a whale sanctuary, mātaitai and taiāpure

${ }^{88}$ Subantarctic Islands Marine Reserves Act 2014.

${ }^{89}$ The Ngā Motu/ Sugar Loaf Islands MPA was established by The Sugar Loaf Islands Marine Protected Area Act 1991, which provides for restrictions on fishing and prohibits mining within the MPA.

901992 Convention on Biological Diversity.

${ }^{91}$ Department of Conservation and Ministry of Fisheries, Marine Protected Areas Policy and Implementation Plan (2005).

92 Ibid at para. 13.

93 Ibid at para. 14.

94 Ibid at para. 18.

95 Ibid at paras. 17 and $62-99$

${ }^{96}$ Ibid at paras. $62-99$.

${ }^{97}$ Ibid at para. 25.

98 Department of Conservation and Ministry of Fisheries, Marine Protected Areas. Classification, Protection Standard and Implementation Guidelines (2008).

${ }^{99}$ Ibid 3.2 and Appendix.

100 Ibid at 3.1 .

101 Ibid at 3.2.

102 Ibid at 3.2.

103 Ibid at para. 2.7.

104 Department of Conservation and Ministry of Fisheries, Coastal marine habitats and marine protected areas in the New Zealand Territorial Sea: a broad scale gap analysis (2011) at 5.

105 Simon A Banks and Greg A Skilleter, "Implementing marine reserve networks: A comparison of approaches in New South Wales (Australia) and New Zealand” 34 (2010) Marine Policy 197 - 207 at 198.

106 Trevor J Willis, Scientific and biodiversity values of marine reserves. A review (DOC Research and Development Series 340) (2013) at 1 .

107 Simon A Banks and Greg A Skilleter, op cit n. 105 at 201.

108 Ibid at 202.

109 MPA Consultation Document (2016) at 13.

110 Simon A Banks and Greg A Skilleter, op cit n. 105 at 203.

111 Ibid at 203.

112 Ibid.

113 MP A Consultation Document (2016) at 13.

114 The 2000 New Zealand Biodiversity Strategy is available at: https://www.biodiversity.govt.nz/Picture/doing/nzbs/index.html

115 MP A Consultation Document (2016).

116 Ibid at 10 .

117 Ibid at $15-16$.

118 Ibid.

119 Ibid at $16-17$.

120 Ibid at 17 .

$121 \mathrm{Ibid}$ at $35-36$.

122 Ibid at 15 .

123 Ibid at 17.

124 Ibid at 5 .

125 Ibid at 17.

126 Ibid at 36 .

127 Ibid at 17.

${ }^{128}$ Ibid at 17.

${ }^{129}$ Ibid at 36.

130 Ibid at 17.

131 Ibid at 17.

132 Ibid at 17.

133 Ibid at 36.

134 Ibid at 17.

135 Ibid at 19.

$136 \mathrm{Ibid}$ at 20 .

137 Ibid at $27-34$.

138 Ibid at 28. 
139 Ibid at 30 .

140 Ibid at 28 and 30 .

141 Ibid at 21. For general information on the Sustainable Seas National Science Challenge see:

http://sustainableseaschallenge.co.nz.

142 Ibid at 22.

143 Ibid.

144 Ibid at $22-24$.

145 Ibid at $22-23$.

146 Ibid at $23-24$.

147 Ibid.

148 Ibid at 23.

149 Ibid at 24.

150 Ibid.

151 Ibid at 37 .

152 Ibid at 25.

153 Ibid at 16.

${ }^{154}$ Commonwealth reserves can be proclaimed within Australia's territorial sea (beyond the 3 nautical mile state/ territory limit) and EEZ under 344 of the 1999 Environment Protection and Biodiversity

Conservation Act.

155 MPAs can be designated in Canada's territorial sea and EEZ under section 35 of the 1996 Oceans Act.

${ }_{156}$ Marine Conservation Zones (MCZs) can be established in the UK's territorial sea, EEZ and continental shelf under section 116(2) of the 2009 Marine and Coastal Access Act.

157 Aichi Biodiversity Target 11.

158 MPA Consultation Document (2016) at 13.

159 Great Barrier Reef Marine Park Act 1975 (Cth), as amended.

160 See generally J C Day, "Zoning - Lessons from the Great Barrier Reef Marine Park" 45 (2002) Ocean and Coastal Management 139.

1611999 Environment Protection and Biodiversity Conservation Act, section 354. See further Brad Jessup and Tim Power, "Marine Parks and Reserves" in Rachel Baird and Donald R Rothwell (eds), Australian Coastal and Marine Law (The Federation Press, Sydney 2011) 264 - 295 and Simon A Banks and Greg A Killeter, op cit n 105.

1621996 Oceans Act, section 35. See further Andrei Whitaker, "Marine Protected Areas in Canada: A Comparative Law Analysis of the Nova Scotia and British Columbia Experience" 28 (2014) Ocean Yearbook $245-268$.

1632009 Marine and Coastal Access Act, sections 117, 123 and 129. Equivalent provisions haven adopted under the Marine (Scotland) Act 2010 and the Marine (Northern Ireland) Act 2013. For further, critical discussion of MPAs in the UK see T Appleby and PJS Jones, "The Marine and Coastal Access Act - A hornet's nest?" 36 (2012) Marine Policy 73 - 77.

164 MPA Consultation Document (2016) at 18.

1652012 Exclusive Economic Zone and Continental Shelf (Environmental Effects) Act, section 59.

166 MPA Consultation Document (2016) at 15.

167 Ibid.

168 Ibid.

${ }^{169}$ Ibid at $15-16$.

170 Ibid at 19.

171 Bill Ballantine, op cit n 9 at 300.

172 Aichi Biodiversity Target 11.

173 Simon A Banks and Greg A Skilleter, op cit n 105 at 198.

174 Ibid.

175 The Joint Nature Conservancy Council (JNCC).

176 See http://www.mcsuk.org/mpa/details/List $\% 20$ of $\% 20$ areas $\% 20$ $\% 20$ English?gclid=COCc0Mf9ucoCFQ18vQod2eoFEg for list of sites.

177 Source: http://www.theguardian.com/environment/2016/jan/17/englands-23-new-marineconservation-zones-branded-useless-by-expert?CMP=Share iOSApp Other.

178 Environment Protection and Biodiversity Conservation (Commonwealth Marine Reserves)

Proclamation 2012 (Federal Register of Legislative Instruments F2012L02188) (repealed).

179 Detailed discussion of the summarized submissions and background to the MPAs is provided in the Report of the Director National Parks under Environment Protection and Biodiversity Conservation Act 1999 Section 351 Concerning the Proposed Proclamation of 40 Commonwealth marine reserves (and the related revocation of seven existing Commonwealth reserves and the revocation of the Coral Sea 
Conservation Zone); and The amendment of the names of four existing Commonwealth marine reserves (October 2012).

${ }^{180}$ Environment Protection and Biodiversity Conservation (Commonwealth Marine Reserves)

Proclamation 2013 (Federal Register of Legislative Instruments F2013L02108).

181 The South-east Commonwealth Marine Reserves network was created in 2007 and its management plan remains in place. Source: https://www.environment.gov.au/marinereservesreview/about.

182 Source: https://www.environment.gov.au/marinereservesreview/regional-review and

https://www.environment.gov.au/marinereservesreview/scientific-review. 